\title{
NURSING WORK ORGANIZATION IN LONG-STAY INSTITUTIONS FOR THE ELDERLY: RELATIONSHIP TO PLEASURE AND SUFFERING AT WORK
}

\author{
Pâmela Patricia Marianoํ, Vanessa Denardi Antoniassi Baldissera², Júlia Trevisan Martins³, Lígia Carreira
}

\footnotetext{
${ }^{1}$ M.Sc. in Nursing. ICU nurse at Hospital Santa Rita de Maringá. Maringá, Paraná, Brazil. E-mail: pamelamariano22@hotmail.com

2 Ph.D. in Nursing. Adjunct professor at the Curso de Graduação e Pós-Graduação em Enfermagem of the Universidade Estadual de Maringá. Maringá, Paraná, Brazil. E-mail: vanessadenardi@hotmail.com

${ }^{3}$ Ph.D. in Nursing. Adjunct professor at the Curso de Graduação em Enfermagem of the Universidade Estadual de Londrina. Londrina, Paraná, Brazil. E-mail: jmartins@uel.br

${ }^{4}$ Ph.D. in Nursing. Adjunct professor at the Curso de Graduação e Pós-Graduação em Enfermagem of the Universidade Estadual de Maringá. Maringá, Paraná, Brazil. E-mail: ligiacarreira.uem@gmail.com
}

\begin{abstract}
The aim of this study was to understand the nursing work organization in long-stay institutions for the elderly and its relationship to pleasure and suffering at work. Data were collected through observation and interviews between April and September 2013 and submitted to content analysis, in light of Dejours' psychodynamics of work theory. Professionals experience suffering as they face physical exertion, a fast-paced work environment and repetitive routines, limited human resources, accumulation of responsibilities and lack of medical service in the institution. Pleasure is experienced through the division of labor among workers, staff's good working relationships, freedom to change the work organization and the possibility of creating a bond with the elderly. The study provides subsidies for planning adequacies in the nursing work organization at these institutions, which will improve the workers' relationship to their work activities.
\end{abstract}

DESCRIPTORS: Nursing. Homes for the aged. Occupational health. Job satisfaction. Stress, psychological.

\section{ORGANIZAÇÃO DO TRABALHO DE ENFERMAGEM NAS INSTITUIÇÕES DE LONGA PERMANÊNCIA PARA IDOSOS: RELAÇÃO COM O PRAZER E SOFRIMENTO LABORAL}

RESUMO: Objetivou-se conhecer a organização do trabalho de enfermagem em Instituições de longa permanência para idosos e sua relação com o prazer e o sofrimento laboral. Os dados foram coletados por meio de observação e entrevista, entre abril e setembro de 2013, e submetidos à análise de conteúdo, à luz da teoria da Psicodinâmica do Trabalho, de Dejours. Os profissionais vivenciam o sofrimento diante do esforço físico, rotina acelerada e repetitiva, recursos humanos escassos, acúmulo de responsabilidades e ausência de serviço médico presencial na instituição. O prazer é vivenciado frente à divisão do trabalho entre os trabalhadores, a boa convivência entre a equipe, a liberdade de modificação da organização de trabalho e a possibilidade de criação de vínculos com os idosos. O estudo fornece subsídios para o planejamento de adequações na organização de trabalho de enfermagem nessas instituições, promovendo a melhoria da relação do trabalhador e sua atividade laboral.

DESCRITORES: Enfermagem. Instituição de longa permanência para idosos. Saúde do trabalhador. Satisfação no trabalho. Estresse psicológico.

\section{TRABAJO DE ENFERMERIA EM INSTITUCIONES PARA PERSONAS DE EDAD Y EL RELACIÓN SUFRIMIENTO-PLACER DEL TRABAJO}

RESUMEN: Objetivo conocer la organización del trabajo de enfermería en Instituciones para personas de edad y su relación con el placer y el trabajo del dolor. Los datos fueron recolectados por medio de observación y entrevistas, entre abril y septiembre de 2013, y sometidos a análisis de contenido a la luz de la teoría de la Psicodinámica Del Trabajo de Dejours. Los profissionales experiencia el sufrimiento antes de un esfuerzo físico, rutina rápida y repetitiva, escasos recursos humanos, acumulación de responsabilidades y falta de asistencia médica en la institución. El placer se experimenta a través de la división del trabajo entre los trabajadores, las buenas relaciones entre el personal, la libertad de modificar la organización del trabajo y la capacidad para formar enlaces con los ancianos. El estudio apoya la planificación de los ajustes en la organización del trabajo de enfermería en instituciones para personas de edad, la promoción de la mejora de las relaciones entre los trabajadores y sus actividades de trabajo.

DESCRIPTORES: Enferméria. Hogares para ancianos. Salud laboral. Satisfacción en el trabajo. Estrés psicológico. 


\section{INTRODUCTION}

Work involves tasks and activities, with "tasks" being what it requested to be done, and "activities", the actual work while performing a task, therefore being divided in "requested work" and "actual work", respectively. ${ }^{1}$ Work organization is the factor that will lead to an activity's development. It consists of the division of labor, job content and power relationships involving the hierarchical system. ${ }^{2}$

People are in daily contact with work organization in their labor context. When the organization does not take into account the employees' needs and expectations and blocks their adaptation possibilities, suffering emerges, which can reverberate in job satisfaction, their personal lives and health. ${ }^{3}$ Although this work can be a source of suffering, it provides, on the other hand, experiences of pleasure, because through it people build their lives and are inserted into the labor market, not only as a means of survival, but also for personal and professional fulfillment. ${ }^{4}$

It is known that the nursing work has great influence on the quality of life of its employees. Its central focus is human being and family care and it is characterized by diversified activities, consisting in a fragmented and hierarchical work systematized in higher and less complex activities according to categories, professionals' knowledge and patients' needs. The nursing scenario requires from workers theoretical and scientific knowledge, abilities, technical skills of various complexities, besides other capabilities such as communication, organization, and critical observation. ${ }^{5}$

The interest of researchers in the sufferingpleasure relationship and the organization of nursing work is growing, especially in intensive care units, and emergency and oncology services. ${ }^{6-11}$ However, there are few studies about this relationship in other nursing practice areas.

Among these areas are the long-stay institutions for the elderly (LSIE), with the aim of sheltering people aged 60 years and over, who are dependent or not, and have no condition of staying with their family or at their home. ${ }^{12}$

The nursing work in these institutions is characterized by intense routines and daily basic care for the elderly. Nursing professionals working in LSIE also suffer intense pressure day-today, so they need to have consistent qualification and training for the effective implementation of activities with the elderly. ${ }^{13}$ As in other areas of nursing practice, the work organization in LSIE also influences the physical and mental health of workers, besides influencing the conducted care.

Given these considerations, the aim of this study was to understand the nursing work organization in LSIE and its relationship to the workers' experience of pleasure and suffering.

\section{METHODOLOGY}

A descriptive and exploratory research, with a qualitative approach, was developed with the nursing staff of six LSIE located in a city in the northwestern region of the state of Paraná, Brazil.

Among the 62 LSIE nursing workers in the study, 40 were nursing technicians, 15 were nursing aides and seven were nurses. The study inclusion criteria were acting for at least six months in the institution and belonging to the permanent staff of the nursing service. These workers were included randomly and according to the willingness to participate in the study. Those who were on leave or refused to participate were excluded. The number of interviews also followed the criterion of saturation of information, that is, until they answered the question of the study. Thus, five workers were included in LSIE A; six in LSIE $B$; seven in LSIE C; three workers in LSIE D; two in LSIE E; and four were interviewed in LSIE F. It is noteworthy that the number of respondents varied from one LSIE to another because of the difference in the number of nursing staff in each institution. At the end of the interviews, 27 nursing workers were included in the study.

Data collection was divided into two stages. First, a nonparticipant observation of the institution's nursing work organization was conducted with a structured script. After the end of the observations in all LSIE, the second stage began, which consisted of individual semi-structured interviews with the following guiding questions: How is nursing work organized in this institution? How is your work in the institution? What feelings do you experience in your work? It is worth mentioning that the interviews were conducted in a specific period for each institution, that is, the interviews for the following LSIE were only initiated after closing the ones from the previous LSIE.

Data were collected from April to September 2013. Interviews were conducted with the aid of a digital recorder, with an average duration of 37 minutes. They content of the interviews was 
transcribed and then analyzed based on the methodological framework of Bardin's content analysis, which consists of a collection of techniques divided into three phases: pre-analysis, data exploration, followed by the treatment of the results, inference and interpretation. ${ }^{14}$

In pre-analysis, successive readings of the interviews were conducted in order to operationalize and systematize data. In the first reading, the points of interest were underlined. Then, there was a new reading to review the points that were previously underlined, in order to ensure the identification of all aspects present in the speeches. In the third reading, the data were organized according to the research objectives, performing data encoding. Encoding means the aggregation of raw data into units which allow description of the content's characteristics, that is, data are organized according to meaning units so they can be grouped, facilitating understanding and further interpretation. ${ }^{14}$

In the stage of exploration, there was a categorization, which is the transformation of raw data into organized data. This process consisted of finding groups and associations to respond to the objectives of the study. For this, the meaning units were grouped according to thematic similarities, which led to three broader categories.

The third and final stage consisted of the content analysis itself, characterized by inference and interpretation of the three categories, relating them to the scientific literature findings.

To better understand the work-health-illness relationship, the findings of this study were discussed in light of the psychodynamics of work, by Christophe Dejours, dedicated to the analysis of the mental processes involved in the confrontation of individuals with the reality of work. Its interest is focused on the experiences of individuals at work, manifested by the suffering-pleasure relationship and by the development of action strategies that favor the normal state of workers in an unstructured work environment. ${ }^{15}$

The development of this study followed the guidelines of resolution 466/12 of the National Health Council and was authorized by those in charge of the institutions and the Permanent Committee on Human Research Ethics, from the Universidade Estadual de Maringá, under protocol n. 207426/2013. ${ }^{16}$ All participants signed two copies of a Free and Informed Consent Form. To ensure confidentiality and anonymity, the interviewees' speeches were identified by the letters $\mathrm{N}$ for nurses; NT for nursing technicians; and NA for nursing aides, followed by Arabic numbers, according to the order in which the interviews were conducted. For institutions, the acronym "LSIE" was used, followed by letters of the alphabet.

\section{RESULTS AND DISCUSSION}

The study participants were five nurses, 12 nursing technicians and 10 nursing aides. Of these, 23 were women, and they worked in all shifts. The age of the workers varied between 22 and 56 years; time exercising the profession varied between 1 and 26 years; and work in the current LSIE, between seven months and nine years. The observation and analysis of the interviews allowed the construction of three categories: the first on the nursing work organization in the institutions, and the others relating to the experience of suffering and pleasure in the nursing work organization in the LSIE, respectively.

\section{Understanding the nursing work organiza- tion in the LSIE}

Among the six institutions, two were philanthropic (LSIE A and B); three were private (LSIE C, $\mathrm{D}$ and $\mathrm{E})$; and one was a governmental institution (LSIE F). Institution B was the one that provided care to a greater number of elderly individuals, 94, followed by LSIE A with 53; LSIE C with 47; LSIE D with 45; LSIE E with 24; and LSIE F with 18 inmates, of whom 15 were elderly.

Regarding the degree of dependence of the elderly, all institutions presented them as fully or partially dependent or independent. This variability on the dependence of the assisted elderly is provided by resolution RDC n. 283/2005 of the Brazilian Health Surveillance Agency with respect to the technical regulations for the operation of the LSIE. ${ }^{17}$ According to this resolution, institutions can provide care in three modalities. The first is aimed at independent elderly individuals, who able to perform self-care. The second refers to the care of elderly individuals with functional dependence in any activity of daily living (partially dependent) such as feeding, mobility, and hygiene, requiring help to perform them. The third modality focuses care directed at elderly individuals with dependency that requires full assistance with specific care on their activities of daily living. It is important to note that LSIE E, at the time of the 
study, presented only one bedridden and totally dependent elderly individuals. A great number of wheelchair users was observed in LSIE B. Institutions $\mathrm{A}$ and $\mathrm{B}$ presented more elderly individuals who were totally dependent on nursing care.

As for the composition of the nursing team, LSIE $\mathrm{A}, \mathrm{B}$, and $\mathrm{E}$ had nursing technicians and aides, whereas LSIE $C$ only had nursing technicians and LSIE D and F only had nursing aides. All institutions also had caregivers in their staff. Two institutions (E and F) did not have a professional nurse. LSIE A was the only one that had a full-time nurse. It is noteworthy that LSIE A, B and $C$ had the highest number of nursing staff and LSIE E only had two nursing technicians and the most caregivers.

Relating the number of workers in the nursing staff and the number of elderly people, especially those with total dependence on care, LSIE A and B stand out, as they had the highest number of professionals. However, they were also the institutions that provided $\mathrm{c}$ to the greatest number of dependent elderly.

Caregivers perform simple and planned actions and are supervised by nurses, such as hygiene, oral feeding, companionship to the elderly, promotion of mobility and comfort. ${ }^{18}$ Observing, recognizing and describing the signs and symptoms, providing hygiene and comfort, checking vital signs, managing medication, performing enteral and oral feeding, among others, are all activities for the nursing technicians. In LSIE, technical nursing plays an important role in supervising caregivers, especially in institutions where the nurse has reduced workload. ${ }^{18-19}$

The nurse performs a more complex care, which requires greater scientific knowledge. This professional develops activities with the elderly through a process of care that consists of looking at patients considering the biopsychosocial and spiritual aspects experienced by the elderly themselves, their family and friends. ${ }^{18}$ Nurses are responsible for managing, which comprises the provision of the required material for the elderly, the elaboration of the workers' monthly schedule, the implementation of forms and standards of the nursing work and caregivers' regime and the activities routine. The nurse also performs the welfare function, related to the implementation of the systematization of nursing care, besides supervising the work of the nursing staff and caregivers. ${ }^{19}$

The institutions received reference assistance from Basic Health Units and other services of the Unified Health System, besides the Mobile Emergency Service. Only two of the institutions (A and B) had the service of volunteer physicians periodically, but still did not have 24-hour medical coverage. Long-stay institutions for the elderly require a multidisciplinary team that can develop proper care for the elderly, providing them with satisfactory quality of life. However, in practice, we see institutions with a deficit of human resources, a lack of doctors, nursing staff and others. Thus, most of the work is carried out by nursing technicians/aides and caregivers, leaving them with an accumulation of responsibilities.

The work routine of all institutions was organized in schedules for the daytime and nighttime periods and included hygiene activities for the elderly, feeding, administration of medications, measurement of vital signs, nursing reports and organization of the workplace. It was observed that all institutions had a higher concentration of activities in the morning, which concerns baths and organization of the dormitories, besides the administration of most continuous prescription drugs.

Regarding the relationship among the nursing staff, it was noted to be permeated by dialogue and mutual cooperation in all LSIE. On the other hand, concerning the relationship between the nursing staff and the administrative leadership, two institutions (LSIE E and F) showed differences of position, compared to the others. In these two, the board of directors had no bond with the nursing staff and caregivers, they maintained dialogue with the team only for supervision and forwarding activities.

\section{Experiencing suffering in the work organi- zation of the LSIE}

Long-stay institutions for the elderly present organizational characteristics that lead the nursing staff to experience negative feelings and labor suffering. Physical strain at work is one of these features, in which professionals perform too much physical effort during hygiene and mobilization of the elderly: I think the work here is heavy, in the physical sense, because they are too debilitated, there are bedridden elderly, so the physical effort here is too much [...] (NA 6; LSIE F); [...] I feel a lot of fatigue [...] we feel a lot of pain in our backs when we lift heavy elderly patients [...] (NT 2; LSIE C).

The reflection of that physical overload on workers' health is observed through musculoskel- 
etal pain, tiredness and fatigue, which can lead to the development of occupational diseases and consequently to physical limitations. Thus, the worker decreases work performance and starts to experience constant pain, which causes suffering. In this scenario, two health problems arising from the suffering of nursing workers stand out: work-related musculoskeletal disorders (WRMD) and the Burnout Syndrome (BS).

Work-related musculoskeletal disorders are characterized by functional and mechanical disorders, muscle, tendon, fascia and nerve injuries, among others, leading to fatigue, work decrease and temporary disability. ${ }^{20}$ Several authors have reported the presence of musculoskeletal disorders among nursing professionals, showing that physical overload, and consequent illness, is already inherent to this area. ${ }^{21-24}$ Nursing professionals develop their activities on an ongoing basis, which involves physical effort, especially by heavy lifting, awkward positions, repetitive movements, thus predisposing them to the risk of illness caused by work, and reducing job satisfaction..$^{22-25}$

The Burnout Syndrome is generally identified among nursing workers. This syndrome is considered the chronicity of occupational stress, being a reaction to the chronic emotional stress surrounding the individual, his or her family and professional contexts. Regarding the employment context, the BS consists of three components or subscales: emotional exhaustion, depersonalization and professional accomplishment. Several studies confirm that the workload is a major factor predisposing to the BS and could negatively influence professional fulfillment. ${ }^{22-24}$

It is important to emphasize that the aim of this study was not to evaluate the incidence of WRMD and BS, but the findings indicate the presence of factors that can lead to the development of these common diseases in the nursing labor scenario. Therefore, it is essential to analyze the environment and the LSIE work organization, as nursing professionals from these institutions may also be affected by these occupational diseases.

Combined with the physical overload of nursing work in LSIE is the fast paced work environment, in which activities should be carried out within a time limit in order not to compromise the following actions. This situation was observed especially in the morning: [...] it is very stressful in the morning, too much of a rush, we have to bathe, make dressings, take the elderly to the cafeteria, give them water... there's no time to stop even for one minute [...]. Work performance is compromised in such a rush (NT 2; LSIE C).

This pressure from timed activities, observed in all institutions, intensifies the suffering relationship of these professionals to work. Suffering happens when there is failure in mediating workers' expectations and the reality imposed by the work organization. ${ }^{2}$ In this sense, it is clear that the fast paced routine environment of the LSIE can compromise the quality of care provided, generating frustration and dissatisfaction in nursing professionals as for the result of their work.

There is a different relationship between the nursing staff and routine activities at nighttime. In this period, the professionals experience a calmer routine due to the characteristics of the performed care and, thus, do not share the complaints of the professionals from daytime: [...] at night it's very different from daytime, we make observations, manage some medications, decubitus changes in bedridden patients. It's calmer than in the morning (NT 3; LSIE C).

The way night work is organized does not generate the suffering that daytime does. This demonstrates that the work itself in LSIE is not harmful to the worker, on the contrary, what can make it dangerous is the way it is organized by individuals. ${ }^{15}$

All nursing staff reported that the work routine of LSIE is repetitive, which leads them to discouragement, compromising their satisfaction: it is very repetitive. Tomorrow I'll be back here and I will do the exact same thing I did today. It will always be the same. Same routine! It's a bit exhausting [...] (NT 12; LSIE A).

Repetitive work under time control leads to monotony and boredom. The imposition of movements that succeed at regular intervals is constantly in conflict with the workers' spontaneous psychic functioning. The consequences are inattention, impaired concentration and even errors and accidents. ${ }^{2}$

The physical demands, the fast pace and repeatability at work were also highlighted in a study in two LSIE in the city of Santos (São Paulo, Brazil), being considered suffering generators. As nursing workers of this study, the professionals of the two LSIE showed physical and emotional exhaustion due to their work routine. ${ }^{21}$

Another noteworthy factor in the LSIE work organization was the task division among the nursing staff through daily activity schedules. It 
was observed that this dimensioning of professionals provides distribution and minimization of the workload and the feeling of repetitiveness: we share the work, we have a scale... we know who is going to bathe, who is going to medication managing. This way it's not too heavy. Since it's alternating, it's calmer. It's great like this (NT 8; LSIE B).

This type of organization was not observed in LSIE D, since in this institution each professional is responsible for a determined number of patients, performing all sorts of care. This organization subjects these workers to higher workload and, consequently, more suffering, when compared to the individuals from the other LSIE under study.

The number of professionals also influences the workers' relationship with their labor activity. The less workers in the team, the greater the workload. Living with this situation generates feelings of distress and dissatisfaction among workers: [...] when someone is missing and there is no substitute, we get overloaded, it overwhelms us and the work becomes very difficult. At the end of the day we are worn down (NA 10; LSIE D); I considered leaving here when employees started missing. It was too much pressure for us to work faster. Very stressful! [...] They thought we'd be able to make it, even with the lack of staff, but we didn't [...] (NT 9; LSIE C).

The lack of human resources for nursing job requirements was also identified by other studies in LSIE, in the intensive care unit and emergency department. ${ }^{9,21,26-27}$ In this sense, it can be considered that nursing work in any area is linked to insufficient staff for the proper conduction of care. This reality is the genesis of suffering at nursing work, since the excess of activities is divided among the available workers, which can compromise care, featuring an exhausting and stressful work situation. ${ }^{26}$

This fact highlights the inadequacy between the requested work and the actual work, this one imposed to workers by the unforeseen, fleeing the schedule. The activity carried out contains adjustments, in an attempt to approach the requirements imposed by the task. In this distance, conflicts between workers and their work usually emerges. ${ }^{1}$

Suffering is also present among the workers that have multiple activities under their responsibility. The accumulation of tasks generates mental overload, making it difficult for professionals to experience pleasure in their work function: here I have a lot of responsibilities. I have to run after everything [...]. I'm always worried about the problems
I need to solve. There are days when I'm overwhelmed and I wonder what to do first. It's complicated because I have to bend over backwards to do it all (NT 11; LSIE E).

Many tasks under the responsibility of an employee are commonly seen in the context of nursing, especially about the nurse. ${ }^{9-10}$ The disharmony between requested work and the actual work is identified because the managers of the LSIE direct various activities to professionals, without the concern of whether they will be able to perform them. Thus, these individuals start to show feelings of displeasure, anxiety and dissatisfaction at work.

The LSIE do not have the same technologies as hospitals, and they also lack 24-hour medical care. Therefore, the nursing staff experiences suffering because of the responsibility to decide on the action to be taken when facing complications with the elderly: I've thought about leaving here, because it's a lot of responsibility. I do have a doctor who is on call, but it's distant. So if something happens, I have to be very well prepared to call the doctor and describe the elderly's situation. I could pass on a mistaken description, which would lead to a wrong prescription. [...] It is too much responsibility (N 3; LSIE B).

In the nursing team, the nurse is the professional who shows greater scientific knowledge to deal with the emergency care in LSIE. However, in two of the institutions, the nursing technicians and aides are the ones who take the lead, because they lack nurses in their staff. This reality creates conflicts among staff, psychological strain before the decisions to be taken, leading to labor suffering: sometimes, when the elderly are sick or have a fever, there is the question: should they be taken to the doctor or not? There are no nurses to decide that. Some would rather take and others would rather not... everyone keeps talking. It would be better if there was a nurse [...] (NA 5; LSIE F).

According to law 7498/86, which regulates the professional practice, in article 11, paragraph I, activities such as planning, organization, coordination, implementation and evaluation of nursing services are found as private activities for nurses. The presence of mid-level/technical nursing workers and other professionals involved in the care requires the presence of nurses to lead and guide them. ${ }^{19}$ In this sense, the two LSIE that lacked nurses present an irregularity, requiring the adequacy according to the law of professional nursing practice. 
This reality found in the study highlights the lack of inspections from the responsible agencies, whether from the direct or the specific elderly nursing care, which enables the maintenance of that irregularity in the work organization of these institutions. In these cases, there is suffering from the nursing workers, who need to adapt to the environment and the unfavorable work organization. The inspection problems in these institutions leave the professionals with a sense of abandonment, since the situation which causes suffering does not present solution, thus enhancing the dissatisfaction and discontentment of the nursing staff with their work. This fact deserves attention from regulatory agencies since it can have negative consequences on workers' health and especially on the quality of care provided to the elderly.

\section{Feelings of pleasure in the process of work organization of the LSIE}

The way that nursing work is organized in LSIE also allows workers to experience pleasure in their work routine. The relationship among the nursing staff and between them and other employees, especially those in leadership, permeated by dialogue, is one of the work organizational characteristics of the LSIE that provides pleasure: [...] we're always talking, getting together, they (nursing technicians) bring me complaints about something so we can try to improve them or I pass them on to the administration, so everyone gets the chance to express themselves. We really work as a team, without distinction, "I am a nurse, I'm the boss, I command you". It's not like that. [...] I always talk with the director, because the doors are open with both him and the president. Here we treat all alike (N 3; LSIE B).

From the perspective of psychodynamics, it is possible to experience pleasure as long as the work organization provides conditions for the development of three major actions by workers: the mobilization of practical intelligence, public space for speech, and cooperation. ${ }^{15}$ It is identified, in the good relationship among the nursing staff and between them and the administration of the LSIE, the mobilization of public space for speech, in which the practical intelligence is recognized and the free expression of opinions is allowed. As it is understood that the worker is able to think, verbalize and speak up his or her ideas and come to a new conclusion or interpretation, the openness for negotiation is promoted, to seek new proposals, developing the process of work organization together. $^{2}$
Thus, institutions that do not have this space for dialogue promote suffering, leading their workers to present feelings of frustration and devaluation: [...] I think we should have psychological support, have someone or the opportunity to talk about it once a month or every three months, to check on our work. That would be great. We need it because the work here is very stressful, not so much physically, but psychologically, because of this rush, these responsibilities. We don't have anyone to talk to about it (NA 5; LSIE F).

When there is no space to talk about the feelings that the job provides, individuals tend to act as if there is stability in the organizational process, which in the long term can lead them to alienation. In contrast, by providing an interpersonal relationship, it creates a favorable environment for individuals to seek the understanding of their work, harmony and cooperation, and strengthening of team work, generating benefits for the worker and for patients assisted by him. ${ }^{6}$

It is through collective communicative actions that the meaning of experienced suffering and, consequently, the most effective coping strategies are built. Thus, the creation of a space for workers to share their feelings, in which a common language that leads to a new intelligibility can be developed, the new interpretation, and a new direction for the work, positively influence the relationship of workers and their work activities. ${ }^{3}$

The mobilization of practical intelligence means breaking the rules and standards, the transgression of requested work via intelligence from the development of more effective means than the work organization itself. ${ }^{15}$ This aspect was identified among the nursing staff who reported the possibility of routine changes in therapeutic approaches and even of the LSIE environment: at first everyone made the dressings and it wasn't working. So I asked if I could be the only one to make them, because I think it's easier to keep the treatment this way. And it really was better than before (NA 1; LSIE B); When I came here I saw that I was able to do something good, different. I saw the opportunity of improving the environment, in the way of working, that's why I am still here today (N 3; LSIE B).

Pleasure is related to the freedom that one has in their labor context, that is, the feeling of being free to think and organize their work through their own initiative, inventiveness and creativity, leading to the transformation of the work organizational mode. ${ }^{28}$ This action enables the subject to appropriate their work activities giving it meaning, besides the construction of their identity at 
work. The results of this process are the experience of pleasure and professional achievement.

The possibility of creating emotional bonds with the elderly is also an example of freedom that individuals have on the work organization. The way that nursing work is developed in LSIE allows workers to do something beyond their functions, providing opportunities for their work to generate pleasure: [...] here you can sit and listen to the elderly, you have time to talk to them, you can play, sing. Here we need to apply the techniques, but we can establish this relationship with the elderly and doing this is very pleasant. I like it (NA 4; LSIE F).

This ability to create bonds with the elderly has been identified in the speeches of all workers interviewed, demonstrating to be a differential in work organization in LSIE. Similar results were found among nursing workers of a hemodialysis service, another example of work organization that provides the individual with freedom of action. ${ }^{29}$

The space of cooperation relates to the collective performance, which is greater than the sum of individual performances, the collective construction being fruit of ideas and services, a common product based on group trust and solidarity. It is characterized by the convergence of the contributions of individual employees and interdependence relationships. ${ }^{15}$ Teamwork, a characteristic of nursing work, emphasizes this space of cooperation: My team is great. We get along, we help each other with the elderly. We are not individualists who say "This is mine.", "I'm done with the care under my responsibility and won't do anything else.", "You do your job and I do mine and that's it." [...]. We're not like that. We do everything together. When one is unable, the other one does it. It's teamwork, really (NT 2; LSIE C).

A good relationship among the staff has a positive effect on the relation of nursing workers and their labor activity, because the collective work helps in experiencing and overcoming situations that cause distress. Other studies with nursing workers demonstrate that positive interpersonal relationships enable the creation of bonds of friendship, confidence and well-being, influencing not only the care provided, but also the individual's relationship to the tensions in their work context. ${ }^{6-7}$

\section{FINAL CONSIDERATIONS}

The way nursing work is organized in LSIE promotes experiences of both suffering and plea- sure for the professionals, which shows that the nursing work activities in these institutions present aspects and situations that generate mixed feelings. This finding is consistent with the perspective of the psychodynamics of work, which clarifies that the pain-pleasure dyad is always present in the work context and it is this relation that allows workers to live with their labor activity.

It is necessary for individuals to identify situations that generate pleasure in order to be a motivational factor for the continuity of their work. Still, it is also important that they be able to recognize the circumstances that cause suffering, so they can develop coping strategies and live with their work.

In this study, the two institutions that do not have nurses stood out, as in these LSIE nursing technicians and aides assume functions that are not within their competence. This situation is not only an indicator of suffering, but, mainly, of irregularity. This negatively influences the relationship between workers and their work, as well as the quality of care provided to the elderly, showing the need for greater attention, from the responsible bodies and inspection of the work organization in LSIE.

Despite the limitation by the feelings and perceptions approach, abstract aspects subject to the influence of the moment the individual is going through, and their singular interpretation, this study made it possible to see the relationship of the work organization in LSIE with the experience of pleasure and suffering of nursing workers, providing information for planning improvements in this scenario.

Given the lack of studies in the literature on the suffering-pleasure relationship of workers in the field of gerontology, our data encourage the development of further studies in order to consolidate the knowledge in this line of research.

\section{REFERENCES}

1. Dejours C. A loucura do trabalho: estudo de psicopatologia do trabalho. $5^{\text {a }}$ ed. São Paulo (SP): Cortez-Oboré; 1992.

2. Lancman S, Sznelwar L, Organizadores. Christophe Dejours: da psicopatologia à psicodinâmica do trabalho. Rio de Janeiro (RJ): Editora Fiocruz; 2011.

3. Dejours C, Abdoucheli E, Jayet C. Psicodinâmica do trabalho: contribuições da escola dejouriana à análise da relação prazer, sofrimento e trabalho. São Paulo (SSP): Editora Atlas; 1994. 
4. Martins JT, Robazzi MLC, Bobroff MCC. Prazer e sofrimento no trabalho da equipe de enfermagem: reflexão à luz da psicodinâmica Dejouriana. Rev Esc Enferm USP. 2010; 44(4):1107-11.

5. Santos PR. Estudo do Processo de Trabalho da Enfermagem em Hemodinâmica: cargas de trabalho e fatores de riscos à saúde do trabalhador [dissertação]. Rio de Janeiro (RJ): Fundação Osvaldo Cruz, Programa de Pós-Graduação em Saúde Pública; 2011.

6. Martins JT, Robazzi MLC. Estratégias defensivas utilizadas por enfermeiros de unidade de terapia intensiva: reflexão na ótica dejouriana. Cienc Cuid Saude. 2012; 11(supl):39-46.

7. Shimizu HE, Couto DT, Merchan-Hamann E. Pleasure and suffering in intensive care unit nursing staff. Rev Latino-Am Enfermagem. 2011; 19(3):56572.

8. Lages MGG, Costa MAO, Lopes, TR, Amorim, FCS, Neto APA, Nascimento IRD, et al. Estratégias de enfrentamento de enfermeiros frente ao paciente oncológico Pediátrico. Rev Bras Cancerol. 2011; 57(4):503-10.

9. Martins JT, Bobroff MCC, Ribeiro RP, Robazzi MLCC, Marziale MHP, Haddad MCFL. Significados de cargas de trabalho para enfermeiros de pronto socorro/emergência. Cienc Cuid Saude. 2013; 12(1):40-6.

10. Gobbi C, Durman S. Sofrimento psíquico no trabalho: percepções de enfermeiros. Rev Tempus Actas Saúde Colet. 2010; 4(1):169-77.

11. Papathanassoglou EDE, Karanikola MNK, Kalafati M, Giannakopoulou M, Lemonidou C, Albarran JW. Professional autonomy, collaboration with physicians, and moral distress among European intensive care nurses. Am J Crit Care. 2012; 21(2):4153.

12. Sociedade Brasileira de Geriatria e Gerontologia, Seção São Paulo. Carta aberta sobre ILPI. São Paulo (SP): SBPGG; 2007.

13. Castro VC, Derhun FM, Carreira L. Satisfação dos idosos e profissionais de enfermagem com o cuidado prestado em uma instituição asilar. Rev Pesq Cuid Fund [online]. 2013 [acesso 2014 Jan 10]; 5(4):493-502. Disponível em: http://www.seer.unirio.br/index. php/cuidadofundamental/article/view/2282/ pdf_1007

14. Bardin L. Análise de conteúdo. Lisboa (PT): Edições 70; 2011.

15. Mendes AM Organizador. Psicodinâmica do trabalho: teoria, método e pesquisas. São Paulo (SP): Casa do Psicólogo; 2007.

16. Ministério da Saúde (BR), Conselho Nacional de Saúde, Comissão Nacional de Ética em Pesquisa. Resolução n. 466 de 12 de dezembro de 2012: diretrizes e normas regulamentadoras de pesquisa envolvendo seres humanos. Brasília (DF): MS; 2012.

17. Brasil. Agência Nacional de Vigilância Sanitária. RDC n. 283, de 26 de setembro de 2005. Regulamento técnico para o funcionamento das instituições de longa permanência para idosos. Brasília (DF): ANVISA; 2005.

18. Santos SSC, Silva BT, Barlem ELD, Lopes RS. O papel do enfermeiro na instituição de longa permanência para idosos. Rev Enferm UFPE [online]. 2008 [acesso 2014 Jan 10]; 2(3):291-9. Disponível em: http:// www.ufpe.br/revistaenfermagem/index.php/ revista/article/view/351/pdf_386

19. Brasil. Lei n. 7.498, de 25 de junho de 1986. Dispõe sobre a regulamentação do exercício da enfermagem, e dá outras providências. Diário Oficial da República Federativa do Brasil, 25 Jun 1986.

20. Ministério da Saúde (BR). LER/DORT: protocolos de atenção integrada à saúde do trabalhador de complexidade diferenciada. Brasília (DF): MS; 2006.

21. Alencar MCB, Montrezor JB. Aspectos da organização do trabalho e os distúrbios osteomusculares: um estudo com trabalhadores em instituições de longa permanência de idosos. Rev Ter Ocup Univ São Paulo. 2010 Jan-Mar; 2(1):15-22.

22. Lelis CM, Battaus MRB, Freitas FCT, Rocha FLR, Marziale MHP, Robazzi MLCC. Distúrbios osteomusculares relacionados ao trabalho em profissionais de enfermagem: revisão integrativa da literatura. Acta Paul Enferm. 2012; 25(3):477-82.

23. Meneghini F, Paz AA, Lautert L. Fatores ocupacionais associados aos componentes da Síndrome de Burnout em trabalhadores de enfermagem. Texto Contexto Enferm. 2011; 20(2):225-33.

24. Mealer M, Conrad D, Evans J, Jooste K, Solyntjes J, Rothbaum B, et al. Feasibility and acceptability of a resilience training program for intensive care unit nurses. Am J Crit Care. 2014; 23(6):97-105.

25. Chaboyer W, Chamberlain D, Hewson-Conroy K, Grealy B, Elderkin T, Brittin M et al. Safety culture in Australian intensive care units: establishing a baseline for quality improvement. Am J Crit Care. 2013; 22 (2):93-102.

26. Martins JT. Prazer e sofrimento no trabalho de enfermeiros em Unidades de Terapia Intensiva: estratégias defensivas [tese]. São Paulo (SP): Universidade de São Paulo, Escola de Enfermagem de Ribeirão Preto; 2008.

27. Kongsuwan W, Locsin R. Thai nurses' experience of caring for persons with life-sustaining technologies in intensive care settings: a phenomenological study. Intensive Crit Care Nurs. 2011; 27(2):102-10.

28. Dejours C. Addendum da psicopatologia à psicodinâmica do trabalho. In: Lancman S, Sznelwar L, Organizadores. Christophe Dejours: da psicopatologia à psicodinâmica do trabalho. Rio de Janeiro: Editora Fiocruz; 2011. p. 57-124. 

ponogara S, Burg G. Pleasure-suffering of nursing study. Rev Gaúcha Enferm. 2010; 31(4):738-45. 